Mehmet Akif Ersoy Üniversitesi Fen Bilimleri Enstitüsü Dergisi 11(2): 195-212 (2020)

The Journal of Graduate School of Natural and Applied Sciences of Mehmet Akif Ersoy University 11(2): 195-212 (2020)

Araştırma Makalesi / Research Paper

\title{
Deneyimsel Öğrenme Yöntemiyle Konut Tarihi Derslerinin Uygulanması: Geçmişten Günümüze Anadolu'da Konut Dersi Örneği
}

\author{
Ayşegül DURUKAN (D) ${ }^{\star}$, Mikail AÇIKEL (D) 1 \\ ${ }^{1}$ Akdeniz Üniversitesi, Mimarlık Fakültesi, Antalya \\ Geliş Tarihi (Received): 24.07.2020, Kabul Tarihi (Accepted): 29.08.2020 \\ $\square$ Sorumlu Yazar (Corresponding author ${ }^{\star}$ ): ayseguldurukan@akdeniz.edu.tr \\ (C) +902422274485 㔯 +902423102258
}

\section{ÖZ}

Tasarım öğrenimi sürecinde yer alan birçok kuramsal ders, somut nesneler üzerinden örneklenerek açıklanır. Öğrenciler kuramsal derslerde soyut kavramları daha kolay anlayabilmekte, ancak somut görsellerdeki nesne veya mekânı algılamakta zorlanmaktadır. Bu doğrultuda yapılan çalışma; Mimarlık Tarihi derslerinin eğitimi için sık kullanılan yöntemler dahilinde anlatım, sunum, tartışma ve maket yapımı döngüsü kullanılarak, öğrencilerin öğrenme sürecine olan katkısını ve mesleki ilgilerini arttırmadaki etkisini ortaya koymak amacıyla gerçekleştirilmiştir. Çalışma; Akdeniz Üniversitesi Mimarlık Fakültesi, İç Mimarlık Bölümü seçmeli dersi (Geçmişten Günümüze Anadolu'da Konut) kapsamında üçüncü sınıfa devam eden 34 öğrencinin katılımı ile hayata geçirilmiştir. Çalışma kapsamında, öğrenciler 6 gruba ayrılmış; Anadolu coğrafyasında yer alan bölge ya da dönemlere ait konutların özelliklerini araştırarak rapor düzenlemişler ve bu raporlar doğrultusunda seçtikleri konut tipinin ölçekli maketini yaparak ders sürecini tamamlamışlardır. Yapılan bu çalışma sonucunda öğrenci kazanımlarını belirlemek üzere dersi alan 34 öğrenciye, 5 ’li likert şeklinde hazırlanmış olan motivasyon etkisi, eğitime olan katkısı ve mesleki deneyim gibi 3 boyutu olan bir anket uygulanmıştır. Elde edilen veriler ışığında, Mimarlık Tarihi derslerinin eğitiminde teorik bilginin maket etkinliği ile desteklenmesinin, öğrencinin öğrenme sürecine katkı sağladığı ve mesleki eğilimini arttırdığı tespit edilmiştir.

Anahtar Kelimeler: Anadolu, konut, konut tarihi, mimarlık tarihi, maket

\section{Application of Housing History Courses by Experiential Learning Method: An Example of Housing Course in Anatolia from Past to Present}

\begin{abstract}
Most of the theoretical courses that involved on the process of design education are explained through exemplification on concrete objects. Students can understand abstract concepts more easily during theoretical classes but find it difficult to perceive the object or space in concrete visuals. The study in this direction has actualized to present the contribution of the students to learning process and the effect on the increase of their professional interest by the methods frequently used on architectural history courses, within the cycle of expression, presentation, discussion and model making. The study took place within the Akdeniz University Architecture Faculty of Architecture, Department of Interior Architecture elective course (the Housings of Anatolia through the Ages) with the contribution of 34 students that are currently on the third year. Within the scope of the study, students were divided into 6 groups; prepared reports on the subjects researching the local or periodical issues of Anatolian geography and completed the course process by making a scale model of the housing type they selected in accordance with these reports. As a result of this study to determine the earnings, a three-dimensional survey prepared in the form of 5 point likert scale questionnaire consisting of; effect of motivation, contribution to education and professional experience has been applied to 34 students that took the course. In the light of the data obtained, it was determined that the support of theoretical
\end{abstract}


knowledge with the model activity in the education of the History of Architecture courses contributes to the learning process of the student and increases her/his professional disposition.

Keywords: Anatolia, housing, history of housing, history of architecture, scale model

\section{GíRiş}

Konut, insanların en temel intiyaçlarından biri olan barınma ihtiyacını güvenli ve sağlıklı bir şekilde karşılayan bir araçtır (Uğur ve Balcı, 2014). Ancak günümüzde konut sadece bir barınak değil ekonomik, siyasal ve kültürel bir unsundur. İnsanlık tarihi kadar eski olan konut, ağaç kovuğundan modern konutlara geçişte binlerce yıllık bir gelişimi yansıtır (Özlük, 2019). Konutun mimarlık tarihindeki yerini Kavas (2009) aşağıdaki şekilde özetlemiştir;

\begin{abstract}
"Mimarlık tarihinin sürekli tekrarlana gelmiş belli baş/ı mimari eserlerle sınırlı kalmasından duyulan rahatsızlık, öncelikle ABD'de XX. yüzyılın ortalarından itibaren dile getirilmeye başlanmıştır. Tarihsel yapı çevrelerinin büyük bir oranını temsil eden konutların, günlük yaşamın geçtiği ticari alanların ve kırsal yapıların da mimarlık tarihi açısından önemli olmaları gerektiği vurgulanarak tapınak, saray vb. gibi Kanonlarda yer alan kalıplaşmış seçkilerin ötesine geçilmesi ihtiyacı hatırlatılmıştır. Bu çerçevede 'sıradan' olarak görülmüş konut yapılarının incelenmesi en az şaheser olarak görülmüş ünlü yapıların incelenmesi kadar önem kazanmıştır."
\end{abstract}

Halk mimarisi üzerindeki araştırmalar, değerlendirmeye ilişkin sağlam bir yöntem olmamasının sıkıntısını her zaman çekmiştir. Bunun nedeni mimarlık tarihinde, eleştiri ve kuramın başlangıç noktasının büyük anıtlar olmasıdır. Anıt güç simgesi, üst kültürel katmanların göstergesi ve seçimlerinin ifadesi ise anonim konut de sıradan kültürün dokusunu yansıtan ve simgeleyen en başat nesnedir. Anıt iktidar ve güce ait uzak anılarla doluyken; konut, sıradan insanın günlük yaşantısına sit izlerle doludur. Yakın çağların demokratikleşmesi, güçlülerin doğal büyüklüklerine indirgenmesini sağlamış; anonim mimarinin araştırılması bu nedenle kabul edilebilir ve hatta saygıdeğer bir uğraş olmuştur (Kuban, 2018).
Ne yazık ki yukarıda bahsedilen Mimarlık Tarihini oluşturan kalıplaşmış felsefe ve kavramlardan dolayı Mimarlık Fakülteleri'nde süregelen Mimarlık Tarihi derslerinde 'konut tarihi' istenilen düzeyde öğrenciye aktarılamamaktadır. Özellikle konut çeşitliliği açısından oldukça zengin topraklara sahip olan Anadolu coğrafyasında bulunan konutların tarihini öğrencilere aktarılması bir zorunluluk haline gelmiştir. Anadolu geçmişten günümüze içinde barındırmış olduğu uygarlıkların çeşitliliğinin etkisiyle, büyük bir kültürel hazinedir (Strabon, 2000). Anadolu'daki konutlar ve yerleşmeler incelendiğinde, yaklaşık on ki bin yıllık bir süre içinde aynı topraklar üzerinde yer alan yerleşmeler, farklı kültürlere ait yaşam biçimleri, farklı coğrafi konumlar ve farklı teknolojilerin biçimlendirdiği büyük bir çeşitliliği sergilendiği görülmektedir (Sey, 1999). Böylesine çeşitliliğe sahip olan 'Anadolu'da Konut' kavramını öğrencilere aktarabilmek için, Türkiye'de 28 adedi İç Mimarlık, 25 adedi ise İç Mimarlık ve Çevre Tasarımı bölümü olarak eğitim veren 53 adet bölüm içerisinde (Izadpanah ve ark., 2020) ilk kez Akdeniz Üniversitesi Mimarlık Fakültesi İç Mimarlık Bölümünde 20192020 Eğitim-Öğretim yılı güz yarıyılında 'Geçmişten Günümüze Anadolu'da Konut' ismi ile 5. Yarıyılda 3. Sınıf öğrencilerine 3 AKTS'lik seçmeli ders olarak açılmıştır.

\section{Geçmişten Günümüze Anadolu'da Konut Dersinin Maket Süreci}

Bu derse başlamadan önce "Giriş" bölümünde açıklanan nedenlerden dolayı öğrencinin dersi daha çok benimsemesi ve mesleği ile bütünleşebilmesi için metotlar araştırılmış ve Karahan (2016)' nın derlemiş olduğu metot seçilerek uygulanmıştır (Tablo 1). Karahan (2016), Türkiye'de yer alan mimarlık fakültelerinde mimarlık tarihi derslerinde kullanılan/ kullanılması mümkün olan yöntemleri iki ana grup halinde sınıflamıştır. 
Tablo 1. Mimarlık tarihi derslerinde kullanılan yöntemler (Karahan, 2016).

\begin{tabular}{|c|c|c|c|}
\hline & Yöntem & Medya & Ōzellikleri \\
\hline \multirow{5}{*}{ Grup A } & Anlatim & \multirow{2}{*}{$\begin{array}{c}\text { Zengin yozil-görsel medya } \\
\text { Soru-cevap } \\
\end{array}$} & Ōăreticic-ögrenci etkileģimi \\
\hline & Sunum & & Sorgulayan ̈̈ğrenci \\
\hline & Tarţ̧̧ma & Mimarlik ürünü & Ūreten ̈̈̈̆renci \\
\hline & Alan gezileri & \multirow[t]{2}{*}{ Gerçek modeller } & $\bar{O}_{z n e ~ k o n u m u n d s} \partial_{\text {ğrenci }}$ \\
\hline & Maket yapamu & & $\begin{array}{c}\text { Kargyllkh iletigim kurma } \\
\text { becerisi }\end{array}$ \\
\hline \multirow[t]{3}{*}{ Grup B } & $\begin{array}{c}\bar{U} \bar{U}_{c} \text { boyutlu } \\
\text { görselleģtirme }\end{array}$ & Mimerlik ürünü & Gözlemleyen öğrenci \\
\hline & Sanal turlar & Bilgisayer Progrema & Ūreten, deneyimleyen äğrenci \\
\hline & $\begin{array}{l}\text { Senal gerçek?" } \\
\text { uygulamalan }\end{array}$ & Dijital modeller & $\bar{U}_{\text {ç boyutlu mekan kavrams }}$ \\
\hline
\end{tabular}

Geçmişten Günümüze Anadolu'da Konut dersi kapsamında yöntem olarak Grup A seçilmiştir. Yöntemde mevcut olan Anlatım, Sunum, Tartışma ve Maket yapımı sırasıyla uygulanmıştır. Yöntemin 4. aşaması olan Alan Gezisi bu yıl dersin ilk defa açılıyor olması nedeniyle tüm gruplar tarafından gerçekleşememiştir. Sadece, 'XXI. yüzyılda Anadolu'da Konut ve Karadeniz Konutları' grubu alan gezisi yapma imkânı bulmuştur. Gelecek yıllarda bu ders kapsamına alan gezileri de eklenecektir.

Anadolu'nun sahip olduğu tarih öncesi çağlardan günümüze kadar gelen kültürel mirasın, tek bir katmanını bile anlamak ve anlatmanın büyük bir özen gerektirdiği gerçeği göz ününde bulundurularak; 'Geçmişten Günümüze Anadolu'da Konut' dersi, teorik ve uygulamanın bir arada kullanılmasıyla işlenmiştir. Eğitim sürecine öğrencilerin aktif olarak katılımı, bilgilerin içselleştirilmesini sağlayan güçlü bir etken olarak karşımıza çıkmaktadır (Harris ve ark., 2001). Mekân tasarımı üzerine eğitim gören öğrencilere, teorik dersin slayt üzerinden işlenmesi ile mekânsal sınır üzerindeki vurguların gerektiği kadar güçlü yapılamaması söz konusu olmaktadır. Bu nedenle ders kapsamında, teorik bilgi: anlatım, araştırma, sunum ve tartışma ile verilmiştir. Daha sonra edinilen teorik bilgi uygulama pratiği ile desteklenmiştir.

Dersin teorik bölümünde Anadolu coğrafyasının (Şekil 1) sahip olduğu konut kültürü üzerinde yoğunlaşılmıştır. Anadolu'nun konut kültürünü anlamak ve bu kültürel değerler ile ilgili algılarımızı açabilmek için Anadolu'da yaşanmış belli başlı dönemler ve bölgesel farklılıklar üzerine odaklanılmıştır. Bu bakış açısıyla Anadolu'da konut Neolitik dönemde: Çatalhöyük konutu, MÖ VIII - VII. yüzyılda: Urartu konutu, M.Ö. I. yüzyılda: Roma Konutu, XIX. yüzyılda: Osmanlı Konutu, XXI. yüzyılda: günümüz konutları bağlamında incelenmiştir. Çok kültürlü Anadolu zenginlikleri ile beraber içinde farklı iklimsel nitelikte bölgeler barındırmaktadır. Bu nedenle ders kapsamında gerçekleştirilen araştırmanın teorik bölümünde ise bölgesel farklılıklara da yer verilmiştir. Bu nedenle Anadolu konutları; Akdeniz, Ege, İç Anadolu, Karadeniz, Marmara, Güneydoğu Konutları olarak ayrıca irdelenmiştir. 


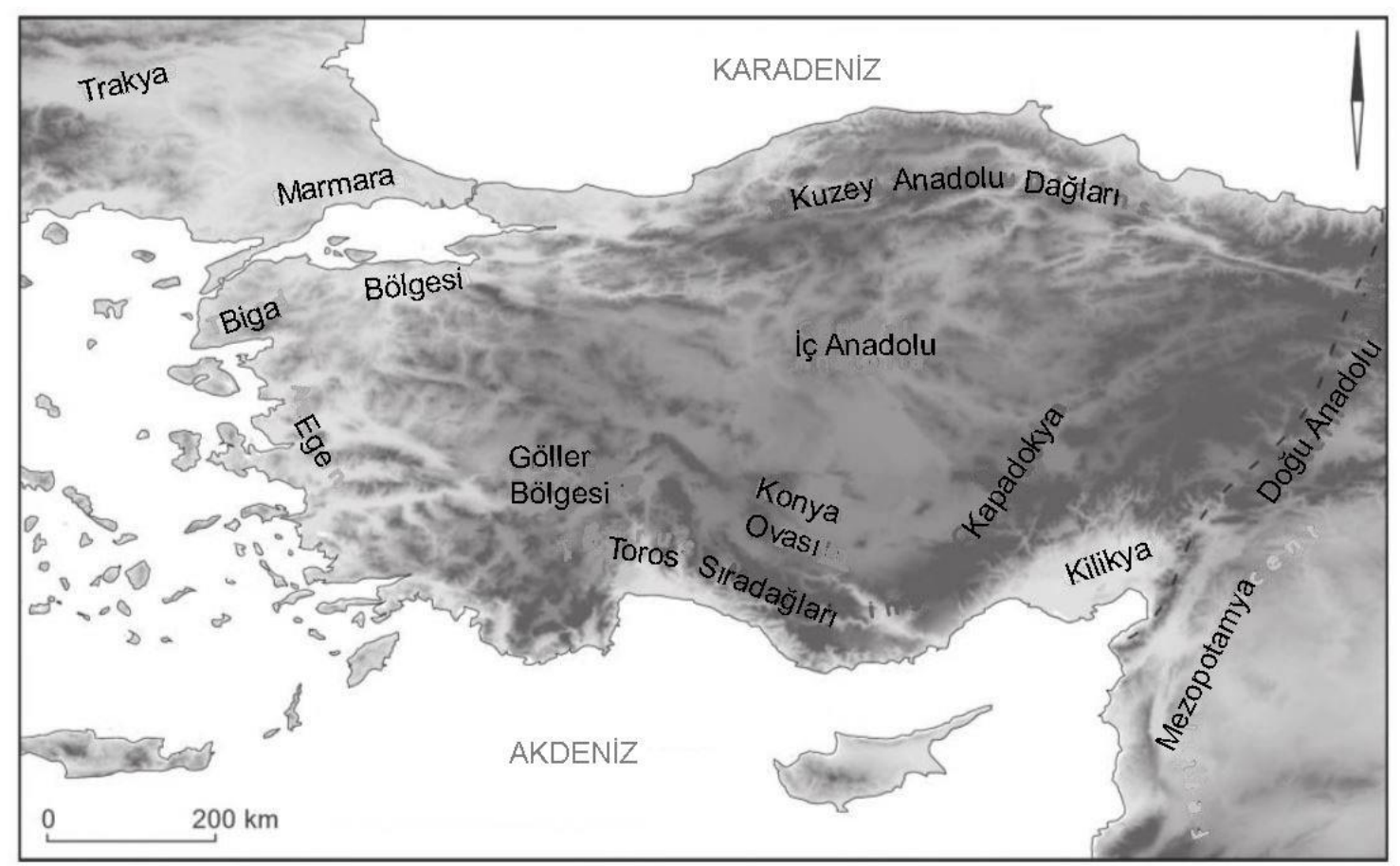

Şekil 1. Anadolu coğrafyası ve toponimleri (Düring, 2010)

Anadolu konut mimarisi hakkında öğrenciler ile birlikte teorik olarak yürütülen iki haftalık ders sürecinden sonra öğrenciler gruplara ayrılarak, kendi ilgi alanlarına göre istedikleri dönem ve bölgenin mimarisi hakkında araştırma süreci içine girmişlerdir. Araştırma dönemi dört hafta içinde tamamlanmıştır. Bu süreç içerisinde yapılan araştırmalar ders içinde sunulmuş ve üzerinde yorumlar yapılmıştır. Araştırma sürecinde öğrenciler, kütüphaneleri aktif bir şekilde kullandıkları gibi konularına göre gerek Akdeniz Üniversitesinin gerek diğer üniversitelerin farklı fakültelerinden akademisyenlerle görüşerek topladıkları bilgileri sınıfta sunmuşlardır. Dersin yürütülmesi sürecinde farklı disiplinler ile bağlantı kurulması teşvik edilmiştir. Bazı gruplar araştırma konularını derinleştirebilmek için Türkiye'nin farklı bölgelerine ziyaretlerde bulunmuşlardır. Bölge halkı ile görüşmeler ve röportajlar yapılmıştır. Bazı gruplar, araştırma süreçleri içinde belediyelerden de bilgi ve destek alınmışlardır. Araştırma, raporlama ve sınıf için sunumların sonucunda her grup, araştırdıkları döneme ya da bölgeye ait bir konut örneği üzerinde odaklanmaya başlamışlardır. 

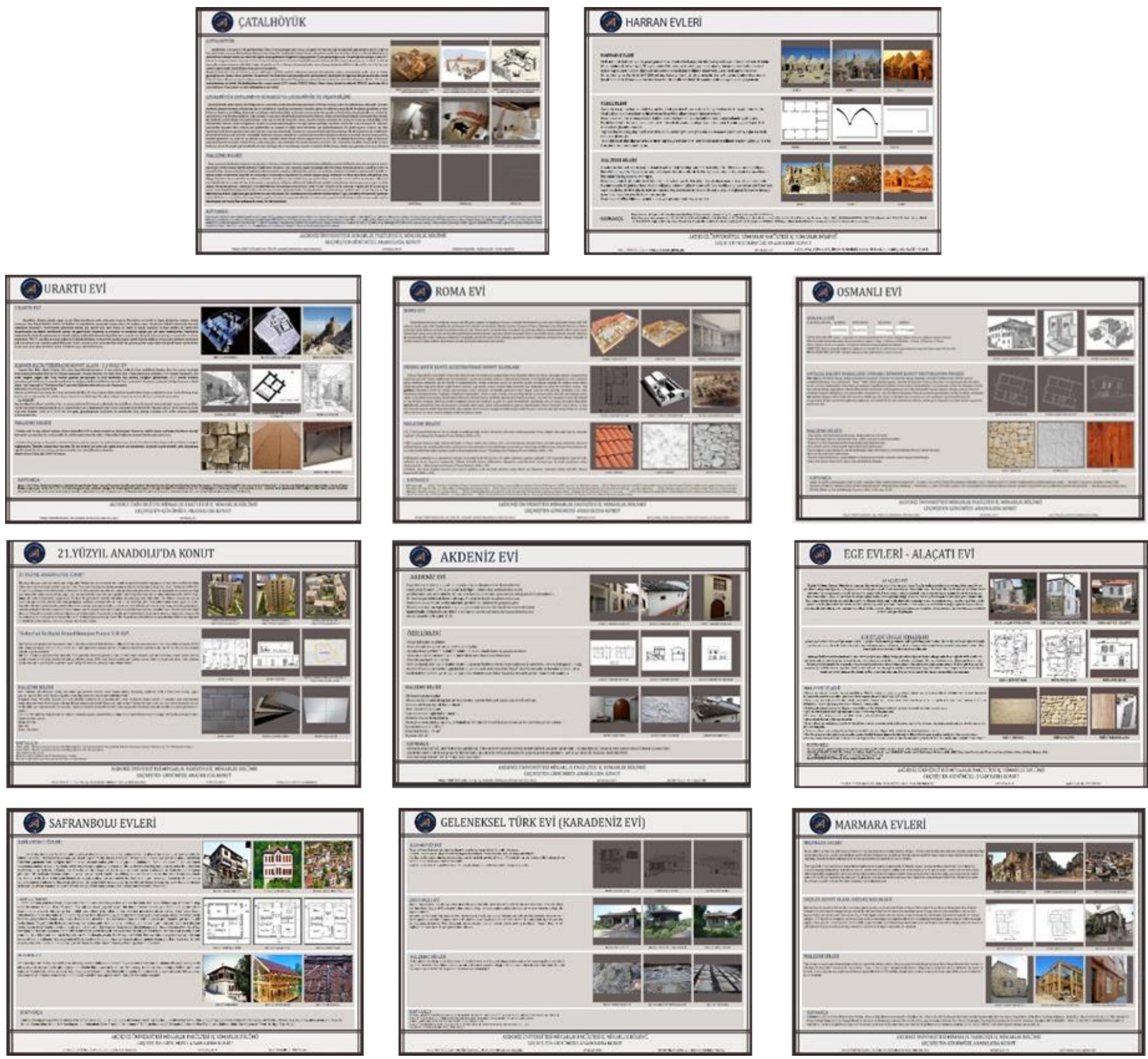

Şekil 2. Geçmişten Günümüze Anadolu'da Konut dersinde yapılan araştırmaların grafiksel dökümü (Durukan, 2020)

Gruplar yaptıkları araştırmada ilk olarak araştırdıkları bölge ya da dönem hakkında rapor hazırlamışlardır (Şekil 2). Gruplar tarafından hazırlanan her raporun akademik etiğe göre yapılandırılması konusunda büyük hassasiyet gösterilmiştir. Araştırma konularının genel mimari özellikleri hakkında verilen bilgiden sonra bu konuları temsilen her grup bir konut planı seçilmiştir. Seçilen konutun özellikleri hakkında da ayrı bir rapor hazırlanmıştır. Hazırlanan bu raporlarda mimari yapı ve malzeme bilgisine yer verilmiştir. Bu raporların özetleri A3 formatında paftalara görseller ile birlikte yerleştirilmiştir. $\mathrm{Bu}$ aşama ile birlikte dersin anlatım, araştırma (araş- tırma sırasında bazı gruplar alan gezilerine de yer vermişlerdir), sunum ve tartışma ile yapılandırılan teorik bölümü neticelendirilmiştir.

Çatalhöyük grubu, Anadolu medeniyetler müzesinde bulunan Çatalhöyük Konut canlandırmasının maket bilgisini, tipik plan olarak kullanmıştır (URL-1, 2019). Urartu grubunda ise Karmir -Blur/Teişebaini sitadeli 2.1 No'lu konut, tipik model (Memiş, 1997) olarak seçilmiş ve bu plan üzerinden çalışmalarını yürütmüştür. Roma grubu; Priene Antik kentinden 33 no'lu konutu tipik plan olarak seçmiştir (Rumscheid, 2000). Osmanlı grubu; Ankara'da 
bulunan Hasan Çerkeş konutunu tipik plan olarak belirlemiştir. Grup bu şekilde aynı zamanda İç Anadolu bölgesinin temsili çalışmasını da yapmıştır (Akok, 1951). Akdeniz grubu; Tekeli Evini tipik konut olarak belirlemiştir (Oral,1996). Ege grubu; Serpil Pekin Alaçatı konutunu tipik plan olarak belirlemiştir (URL-2, 2019). Karadeniz grubu; Rize Fındıklı konutunu seçmiştir (Güler, 2012), Marmara grubu ise İstanbul, Zeyrek evlerinden bir örnek seçerek çalışmalarında bu konutun planını kullanmıştır (Tosun, 1998). Güneydoğu Anadolu grubu ise Geleneksel konik kubbeli Harran konut tipi üzerine araştırma yapmış ve bu bölgenin tipik konutlarından plan örneği seçerek, çalışmalarına bu yönde devam etmişlerdir (Özdeniz ve ark. 1998). XXI. yy grubu ise Antalya'da şu anda yapılmakta olan kentsel dönüşüm projesine ait bir $3+1$ konutu seçerek araştırma, tartışma, maket ve nihayetinde sergi sırasında sunumlarını gerçekleştirmişlerdir.

Araştırmalar sonucunda belirlenen konut planları gerçek planlarına sadık kalınarak 2 ve 3 boyutlu çizimlere aktarılmıştır. Bu aktivite sırasında öğrencilerin tarihi ve bölgesel dokuyu hissetmeleri ve tematik bütünün içine girmeleri hedeflenmiştir. Bu çizimlerle öğrencilerin, konutların tarihsel dokusunu ve bölgesel farklılıklarını bütünsel olarak algılaması hedeflenmiştir. Ayrıca seçilen konutların mekan organizasyonun kavranması ve konut yapımında kullanılan malzeme bilgisinin nedenleri ve niçinleri ile birlikte algılanması amaçlanmıştır. Teorik bilginin; uygulama ile bütünleştirilerek, öğrenci belleğinde anlam kazanması amaçlanmıştır. 2 ve 3 boyutlu çizimlerin yapılması iki haftalık bir süreç içerisinde tamamlanmiştır.

Maket yapımı süreci için 6 haftalık bir zaman dilimi ayrılmıştır. Bu dönem zarfında Çatalhöyük, Urartu, Roma, Karadeniz Konutu, Harran konutu ve XXI. yy modern konutu olmak üzere 6 konut tipi seçilerek maket aşamasına taşınmıştır. Bu aşamada sınıftaki gruplar birleşerek, 6 farklı gruba dönüştürülmüştür. Birçok kültürel katmanı içinde barındıran eşsiz Anadolu konut mimarisini, hissetmek ve algılamak için araştırılarak çizime dökülmüş planların, maket haline getirilmesi bu aşamadan sonra gerçekleştirilmiştir (Şekil 3-4). Geçmişten Günümüze Anadolu'da Konut Mimarisi dersinde çıkan ürünler Akdeniz Üniversitesi Mimarlık Fakültesi'nde 18 Eylül 2019 24 Ocak 2020 tarihleri arasında sergilenmiştir (Şekil 510). Sergide, maketlerin arkasında öğrencilerin araştırma sürecinde hazırladıkları grafikler yer almıştır. Öğrenciler, sergi sürecinde maketlerin ve grafiklerin başında durup çalışmasını yaptıkları Anadolu konutları hakkında katılımcılara bilgi vermiş ve çalışmanın aşamalarını aktarmışlardır. Sergiden 4 hafta sonra maketler için özel kaideler yaptırılarak maketlerin Akdeniz Üniversitesi Mimarlık fakültesinin iç avlusunda kalıcı olarak sergilenmesi sağlanmıştır (Şekil 11). 

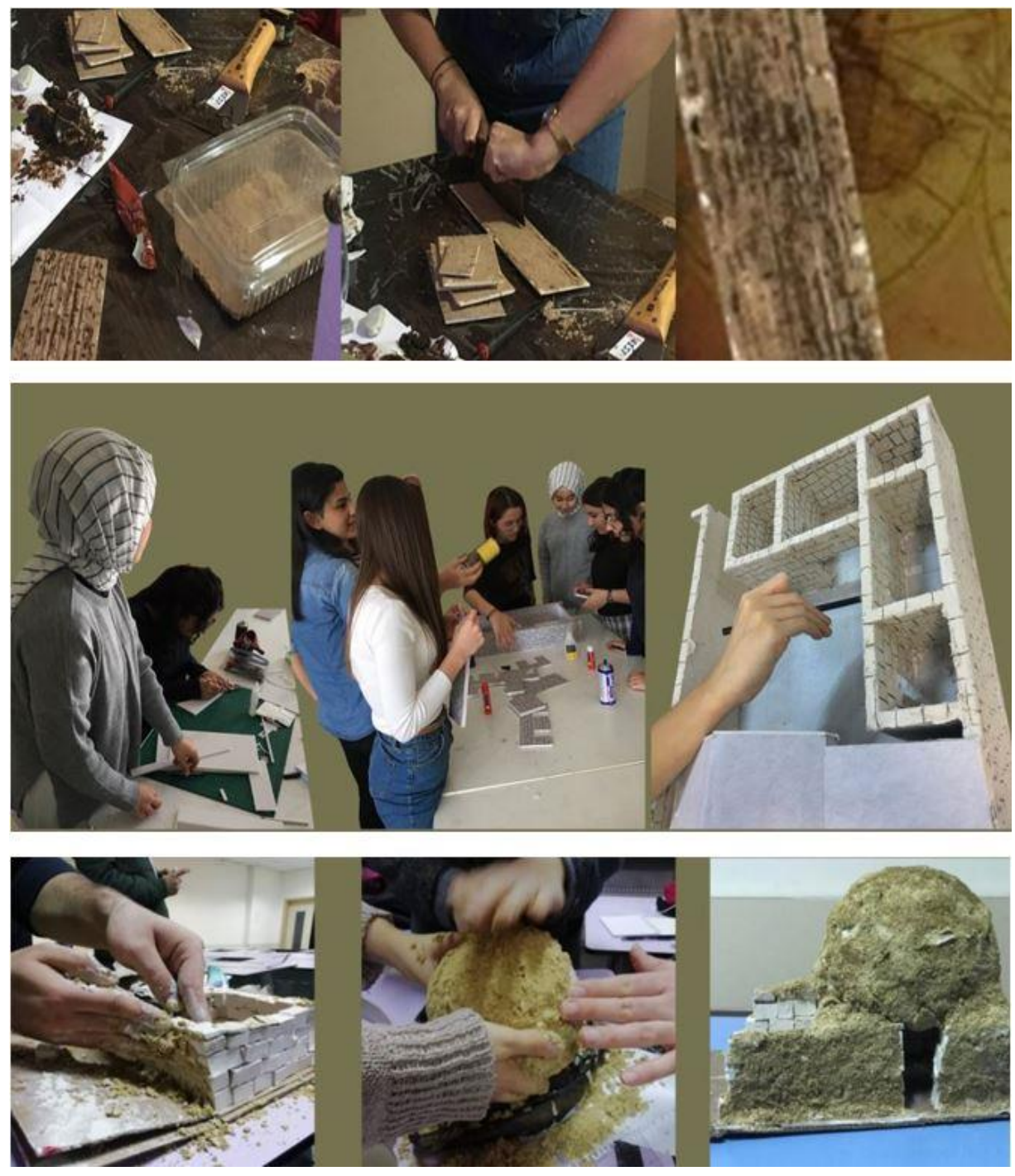

Şekil 3. Maket yapım süreci (Durukan, 2020)
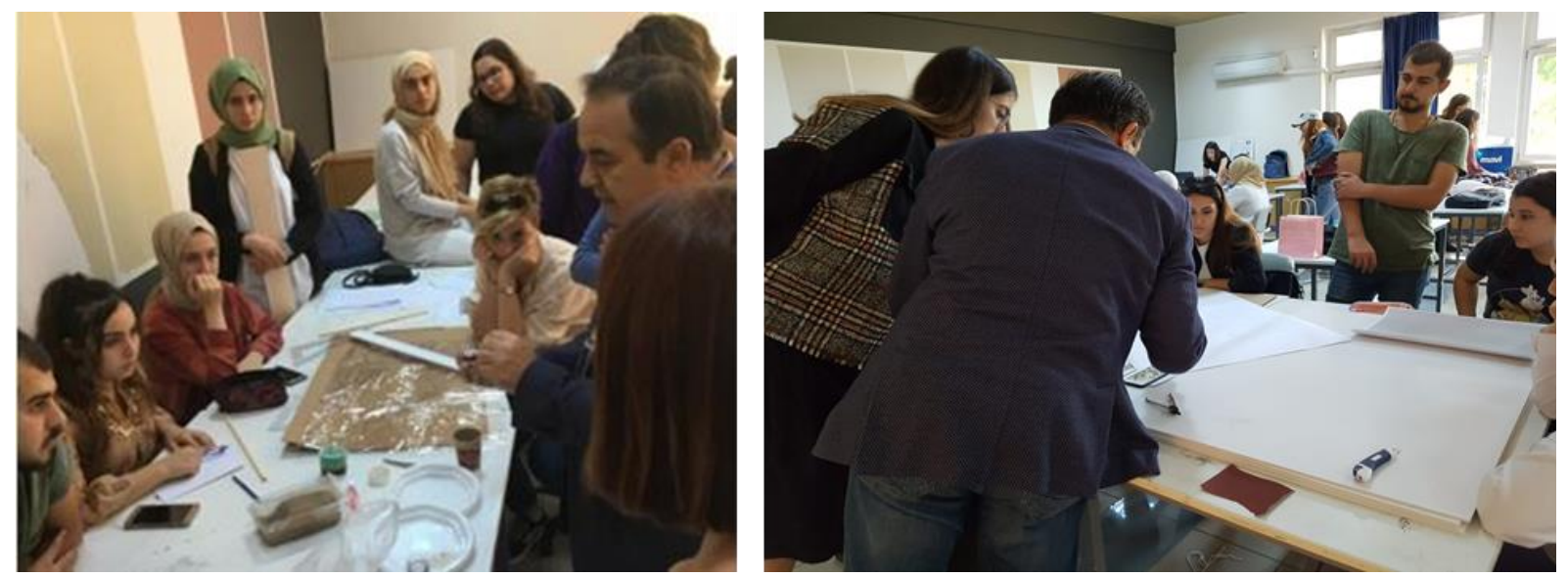

Şekil 4. Maket yapım tekniği (Mimar Zeki Bellikli'nin katıımıyla) 

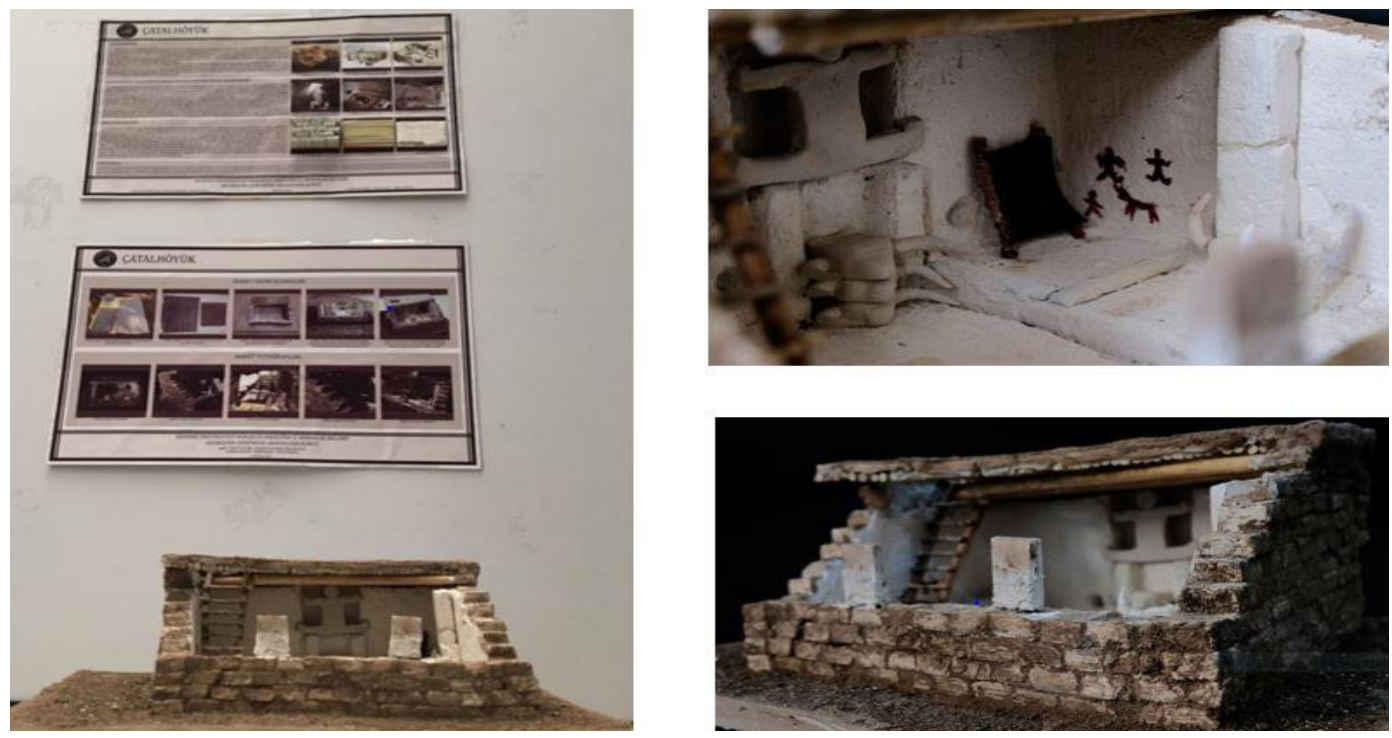

Şekil 5. Çatalhöyük Konutu araştırma raporu ve maketi (Görkem Özdemir, Neşem Bolat ve Nimet Gezginç'e ait çaIışma)
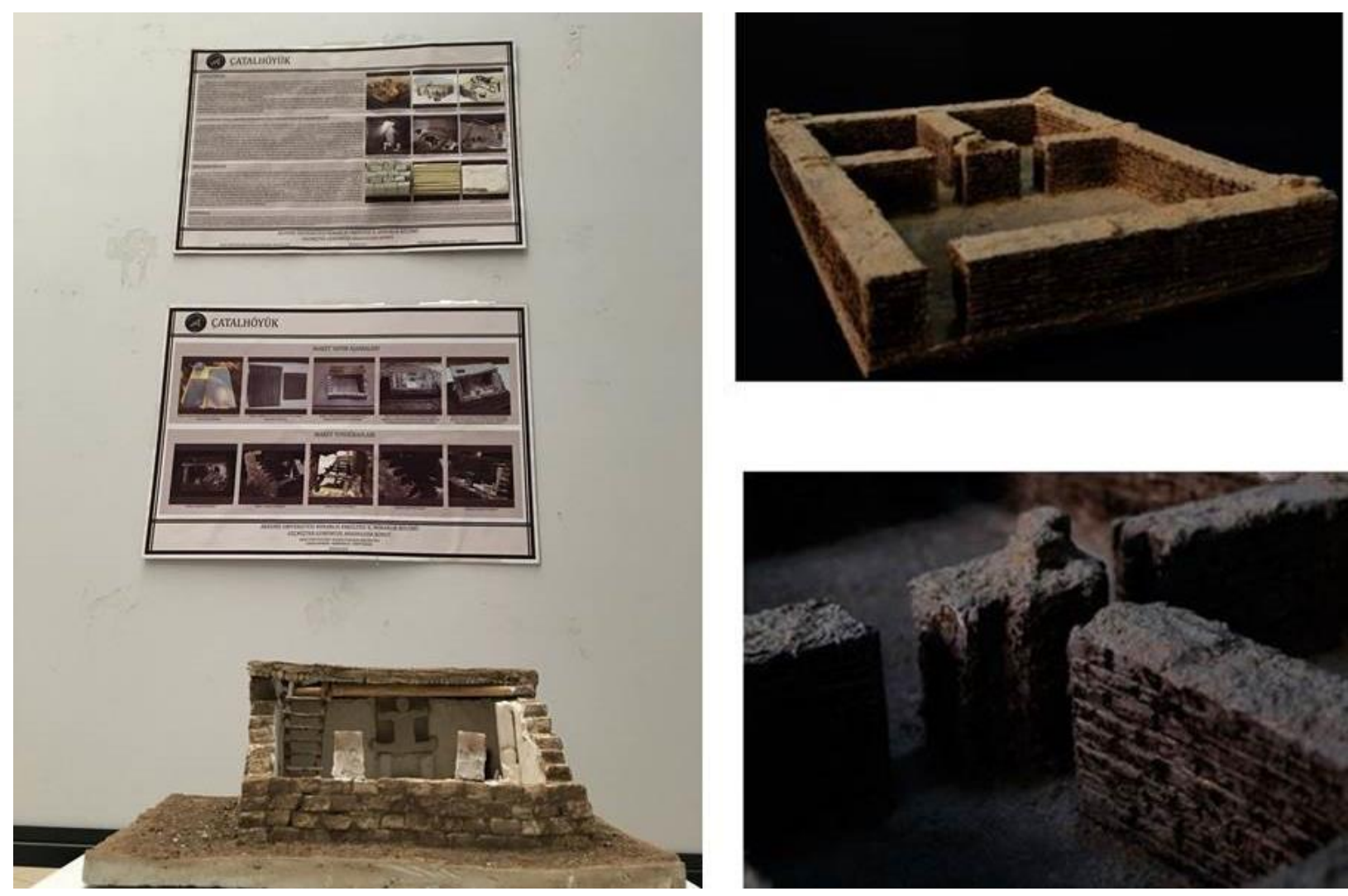

Şekil 6. Urartu Konutu araştırma raporu ve maketi (Beyza Zeren ve Cansu Basit'e ait çalışma) 

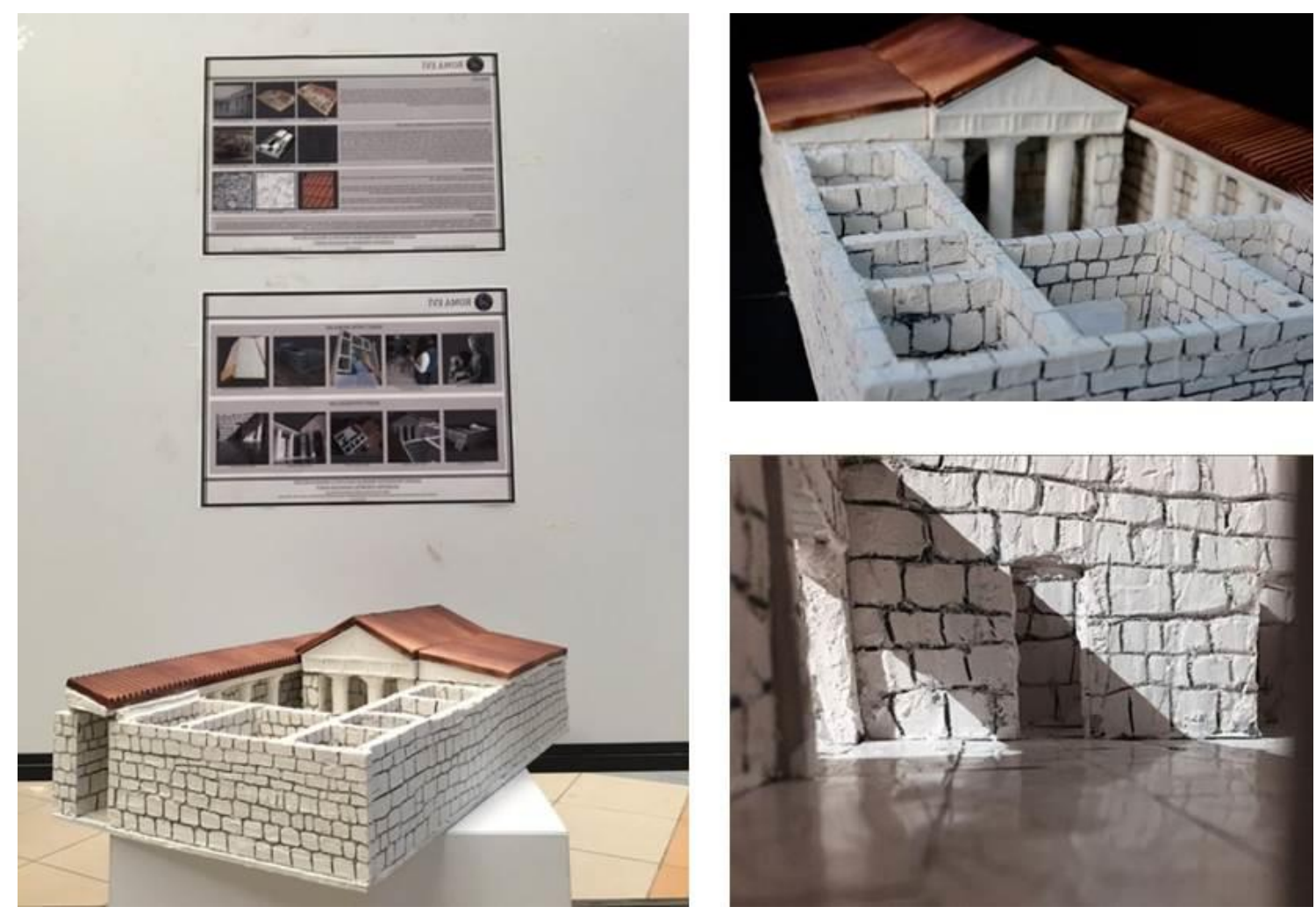

Şekil 7. Roma Konutu araştırma raporu ve maketi (Ayşegül Çelik, Deniz Bonakdar, Ekin Elinç, Elina Andamova, Gizem Bayramoğlu, İlayda Salihoğlu, İrem Temiziç, R. Dilara Türk, Yaren Akın'a ait çalışma)
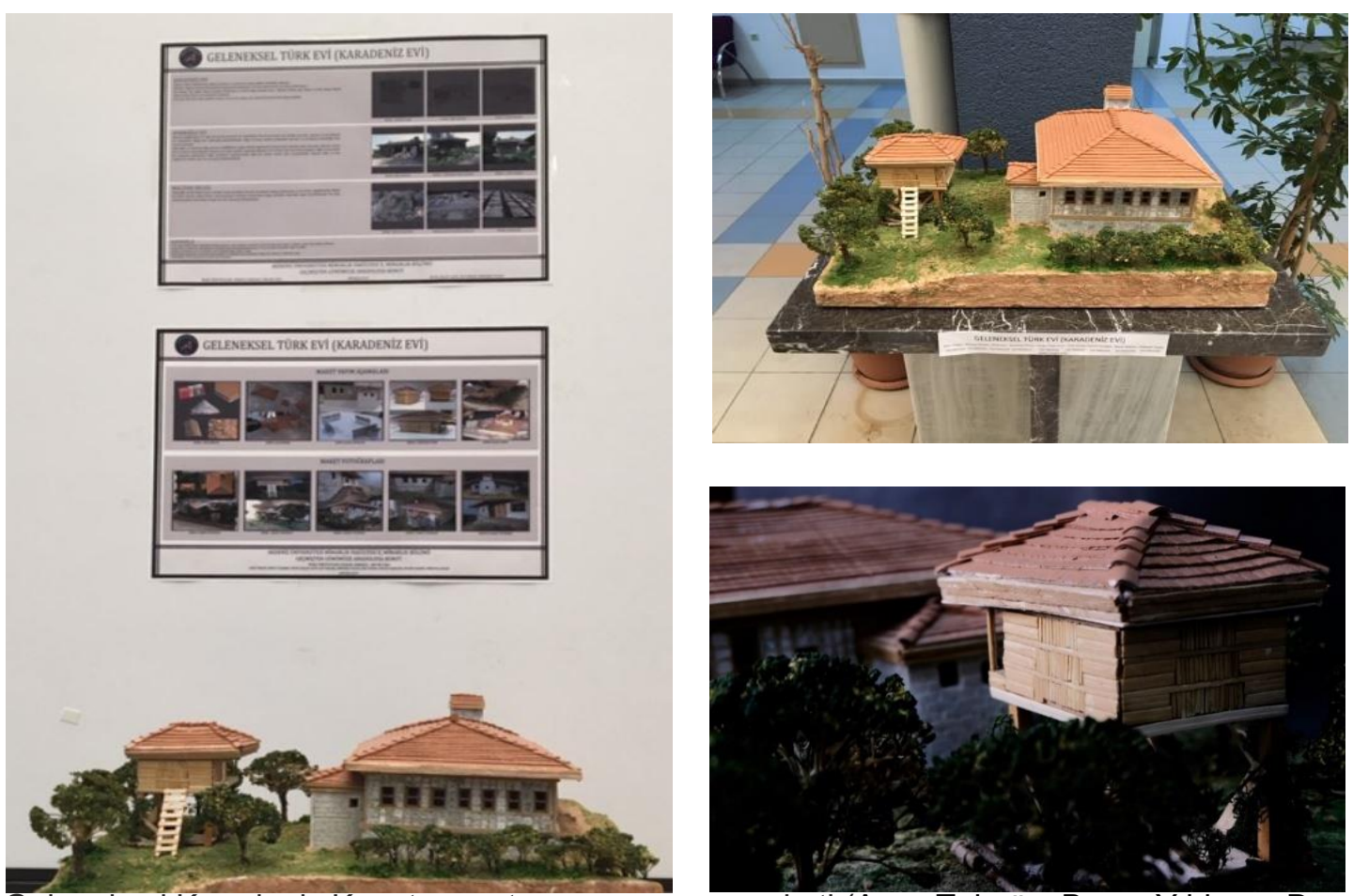

Şekil 8. Geleneksel Karadeniz Konutu araştırma raporu ve maketi (Ayşe Tokgöz, Burcu Yıldırım, Duygu Dilşat Acun, Elif Ersara, Menekşe Yılmaz, Nisa Güneş, Seyhan Karagöz, Zeynep Doksöz, Zübeyde Cengiz'e ait çalışma) 

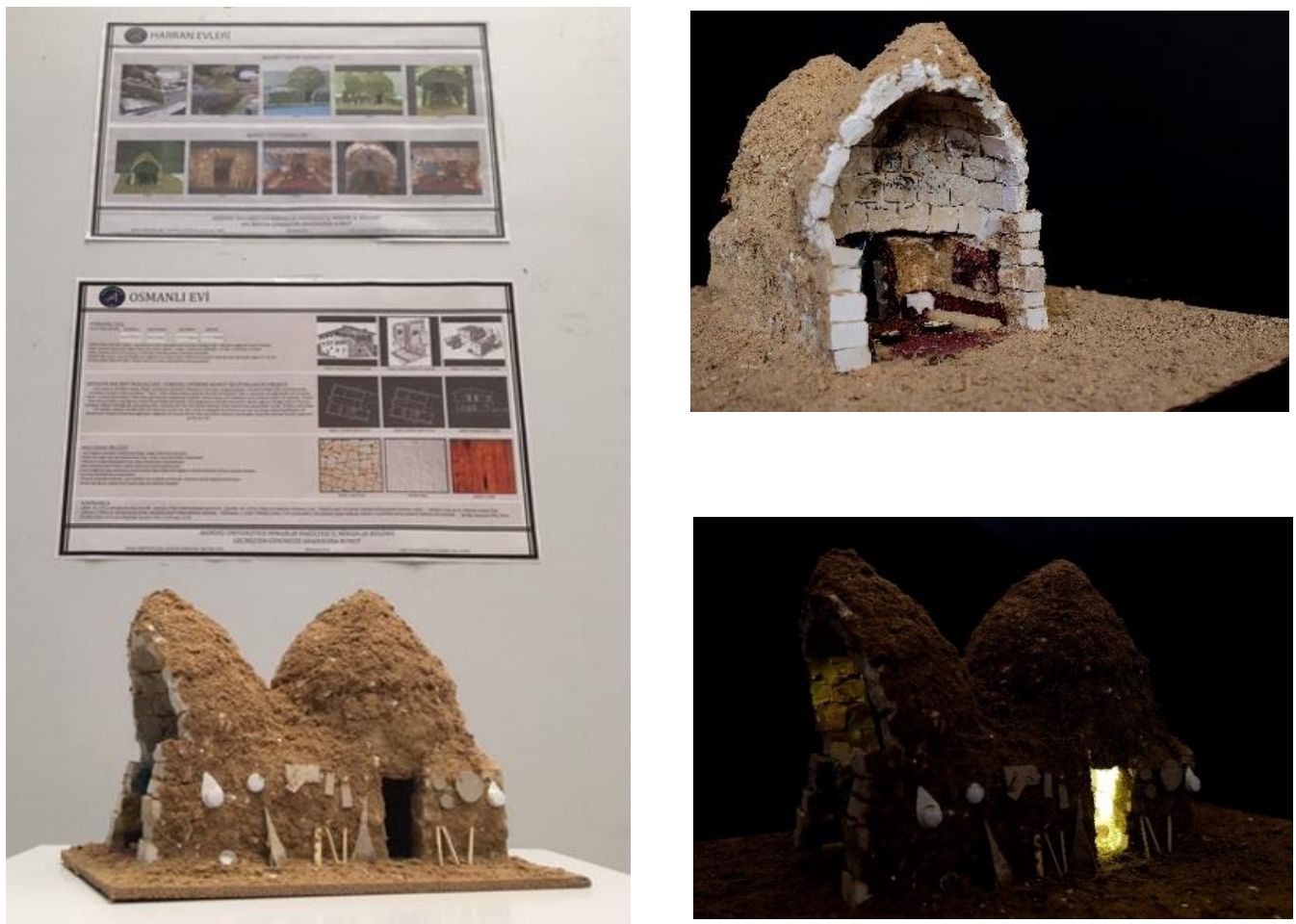

Şekil 9. Harran Konutu araştırma raporu ve maketi (Atike Çetin, İbrahim Rahimli, Nesibe Nur Eke, Elif Genç, Kazım Yiğit Turan'a ait çalışma)
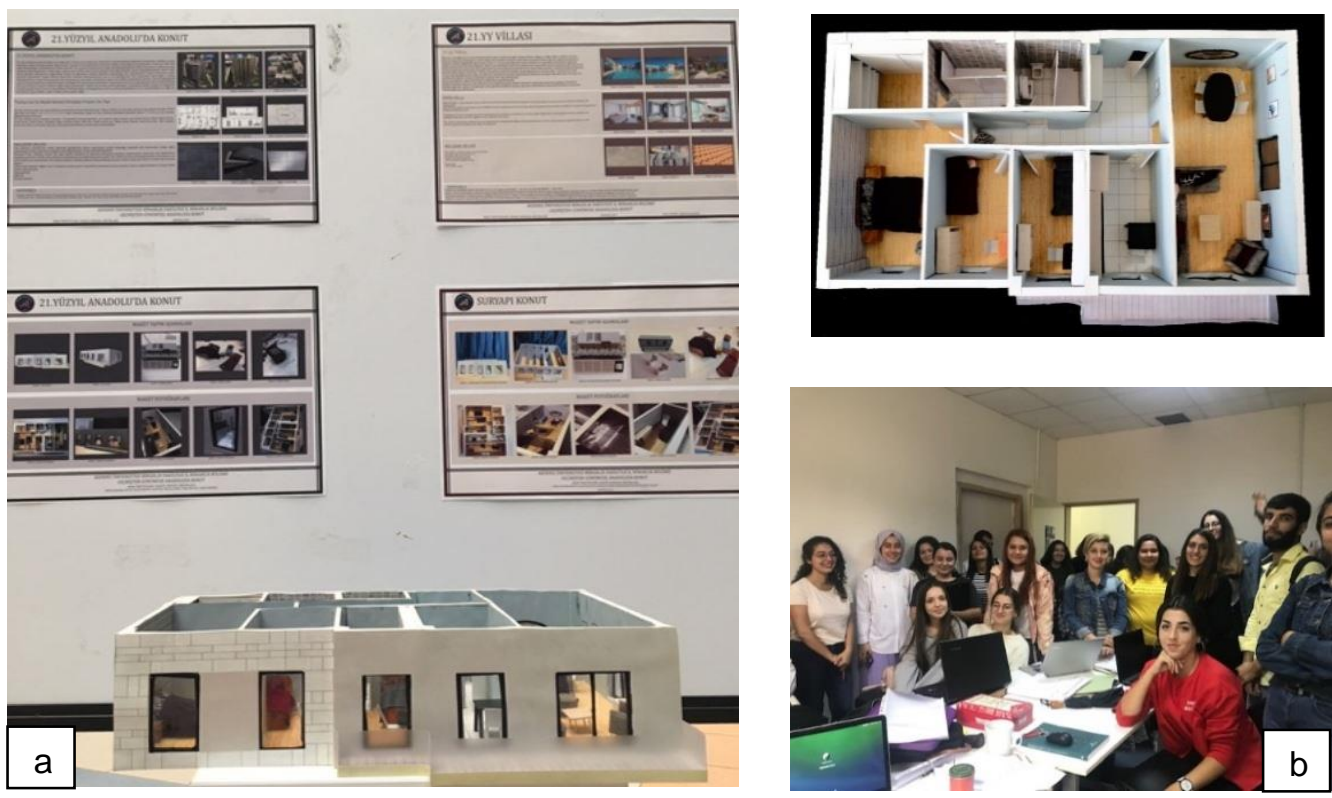

Şekil 10. a. Anadolu'da XXI. yüzyıl konutu araştırma raporu ve maketi (Ceyda Karakaş, Duygu Yalçın, Mehtap Aslantaş, Melisa Şahin, Tuğba Güngör, Yaren Korkmaz'a çalışma). b. Geçmişten Günümüze Anadolu'da Konut Dersi öğrenci toplantısından bir kare. 


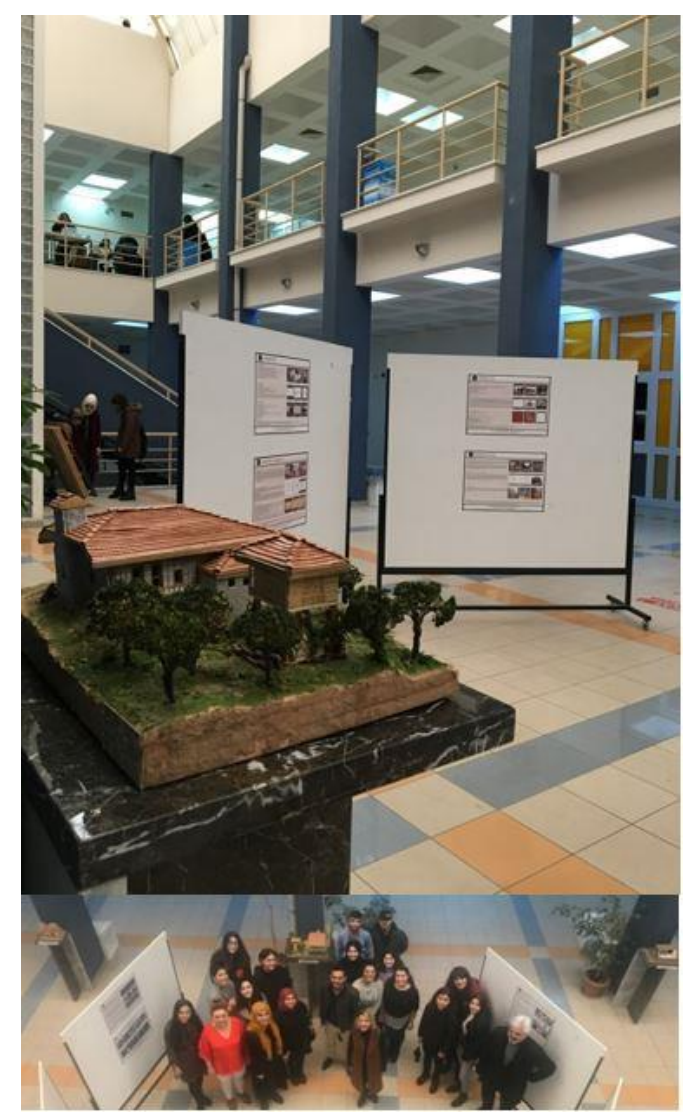

Şekil 11. Akdeniz Üniversitesi Mimarlık Fakültesi İç Avlusu Kalıcı Sergi

\section{MATERYAL VE YÖNTEM}

Çalışma öğrencilerin ders kapsamında yapılan maket çalışması sonrasındaki deneyimlerinin 4 bölümden oluşan anket çalışması ile ölçüldüğü nicel tarama yöntemine göre yapılmıştır. İlk bölüm öğrencilerin sosyo-demografik durumunu (1), ikinci bölüm yapılan çalışmanın öğrencilere sağladığı motivasyon ölçümünü (2), üçüncü bölüm çalışmanın iç mimarlık eğitimine olan katkısını (3), son bölüm ise öğrencilerin mesleki deneyimlerine olan katkısını ölçmeye (4) yönelik hazırlanmıştır. Çalışmada uygulanmış olan anket çalışmasının bölümlerini oluşturan parametreler Ertaş Beşir ve ark. (2020)'nin yapmış olduğu çalışmadan değerlendirilerek oluşturulmuştur.
Anket çalışması içerisinde "Likert Tutum Skalası" ölçeği kullanılmıştır. Belirlenen 17 parametre öğrencilerin anlayabileceği 17 soruya dönüştürülerek hazırlanmıştır. Parametrelere ait soru ölçeği 5 'li olup 'Kesinlikle katılmıyorum', 'Katılmıyorum', 'Fikrim yok', 'Katılıyorum', 'Kesinlikle katılıyorum' değerlendirmelerini içermektedir (Tablo 2).

Ders kapsamında yapılan çalışma "Motivasyon etkisi", "Eğitime Katkısı" ve "Mesleki deneyim" başlıklarına göre 3 ana grupta toplanmıştır. Bu gruplar altında sıralanan ifadelerle değerlendirme yapılmıştır. Öğrencilerin yaptığı çalışma ile kazanımlarını ölçmek için "Motivasyon etkisi" parametresine dair 5 soruya yer verilmiştir. "Eğitime katkı" 9 ve "Mesleki eğilim" 3 soruya yer verilmiştir (Tablo 2). 
Tablo 2. Öğrenci kazanımlarını belirlemek için kullanılan anket çalışması (Likert Tutum Skalası)

\begin{tabular}{|c|c|c|c|c|c|c|}
\hline & & - & & 0 & & + \\
\hline & Kazanımlar & 1 & 2 & 3 & 4 & 5 \\
\hline \multirow{5}{*}{ 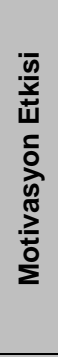 } & Araştırma ve Uygulamaya yönelik çalışmak motivasyonumu sağladı & & & & & \\
\hline & Konumu anlamak için gerekli araştırmayı yapmış olmam motivasyonumu sağladı & & & & & \\
\hline & Araştırdığım konu içinde maketini yapacağım konutin planını seçmek motivasyonumu sağladı & & & & & \\
\hline & Araştırarak öğrendiğim tarihi mekânın planını çizmek motivasyonumu sağladı & & & & & \\
\hline & Araştırarak öğrendiğim tarihi mekânın maketini yapmak motivasyonumu sağladı & & & & & \\
\hline \multirow{9}{*}{ 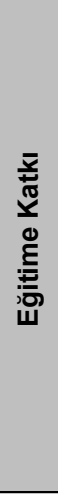 } & $\begin{array}{l}\text { Geçmişten Günümüze Anadolu'da Konut dersi sırasında yapılan çalışma incelediği konu hakkında kalıcı } \\
\text { bilgi edinmemi sağladı }\end{array}$ & & & & & \\
\hline & Araştırdığım dönemle ilgili teorik bilgiyi edinmiş oldum & & & & & \\
\hline & Tarihi mekânları daha net öğrenmiş hissediyorum & & & & & \\
\hline & Geçmiş dönemlerde yapılan mekânların, yapım tekniklerini daha iyi anlayabiliyorum & & & & & \\
\hline & Tarihi dönemlerdeki mekân ihtiyacı ve mekân çözümü arasındaki bağlantıyı anladığımı düşünüyorum & & & & & \\
\hline & İhtiyaca yönelik mekânın şekillenmesi ne demek daha iyi anlayabiliyorum & & & & & \\
\hline & Anadolu hakkında daha net bir bilgi sahibi oldum & & & & & \\
\hline & Anadolu dönem mimarisi hakkında daha net bir bilgi sahibi oldum & & & & & \\
\hline & Anadolu dönem mobilyası hakkında daha net bir bilgi sahibi oldum & & & & & \\
\hline \multirow{3}{*}{ 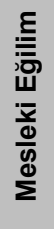 } & $\begin{array}{l}\text { Bir konuyu araştırarak başlayıp } 3 \text { boyutlu hale araştırmamı taşıdığım için kendimin öğrenme, araştırma } \\
\text { ve uygulama konularında yeterli bir düzeyde yeteneklere sahip olduğumu gördüm }\end{array}$ & & & & & \\
\hline & Mesleki donanımı kullanarak, çok farklı araştırmalar yapıp yürütebileceğimin farkındayım & & & & & \\
\hline & Dersin bir zorunluluktan çok, kendimi ifade edebileceğim bir paylaşım platformu olduğunu g & & & & & \\
\hline
\end{tabular}

Ders kapsamında yapılan çalışmanın istatiksel çözümünde faktör analizi, korelasyon analizi ve frekans dağıIımları incelenmiştir (Tablo 2). Faktör analizi, çalışmanın öğrenciler üzerindeki etkilerini belirlemek için yapılmıştır. Belirlenmiş olan değişkenler üzerinden bütün bir bilgiye ulaşılıp yorumlanmasına olanak sağlayan bu analiz 3 başlığa dair belirgin parametrelerin ortaya çıkmasında yardımcı olmuştur. Bu parametrelere ilişkin ifadeler faktör analizinde en çok kullanılan Varimax rotasyonu ile gruplandırılmıştır.

\section{Geçmişten Günümüze Anadolu'da Konut Dersi Öğ- renci Grubu}

2019-2020 Eğitim-Öğretim yılı güz yarıyılında seçmeli olan 'Geçmişten Günümüze Anadolu'da Konut' dersini 34 öğrenci seçmiştir. Bu öğrencilerden 3'ü Erkek, 31'i Kadın öğrencidir. Dersi seçen öğrencilerin en küçüğü 20 yaşında en büyüğü 28 yaşında olup grubun yaş ortalaması 21,4'tür. 34 öğrenci arasında 3 tanesi yabancı uyruklu, 4 tanesi yatay geçiş öğrencisi ve 2 tanesi uzatma öğrencisidir. Öğrenciler arasında en yüksek GANO 3,68 en düşük GANO 2,45'tir. GANO ortalaması 3,10'dur. Sadece 1 öğrencinin GANO'su 2,50'nin altındadır. 27 öğrencinin GANO'su 3.00 'ün üstünde ve bu öğrencilerden 6 öğrencinin GANO'su 3,50'inin üzerindedir (Tablo 3). 
Tablo 3. Öğrencilerin sosyo-demografik durum analizi

\begin{tabular}{|c|c|c|c|}
\hline Parametreler & Değişkenler & Sıklık & $\%$ \\
\hline \multirow{7}{*}{ Yaş } & $15-20$ & 1 & 2,94 \\
\hline & $20-25$ & 32 & 94,12 \\
\hline & $25-30$ & 1 & 2,94 \\
\hline & $30-35$ & 0 & 0 \\
\hline & $35-40$ & 0 & 0 \\
\hline & +40 & 0 & 0 \\
\hline & Toplam & 34 & 100 \\
\hline \multirow{3}{*}{ Cinsiyet } & Erkek & 3 & 8,82 \\
\hline & Kadın & 31 & 91,18 \\
\hline & Toplam & 34 & 100 \\
\hline \multirow{5}{*}{ Öğrenci Profili } & Uzatma & 2 & 5,88 \\
\hline & Yabancı Uyruklu & 3 & 8,82 \\
\hline & Yatay Geçiş & 4 & 11,77 \\
\hline & Diğerleri & 25 & 73,53 \\
\hline & Toplam & 34 & 100 \\
\hline \multirow{5}{*}{ GANO } & 2,50 altı & 1 & 2,94 \\
\hline & $2,50-3,00$ & 6 & 17,65 \\
\hline & $3,00-3,50$ & 21 & 61,76 \\
\hline & $+3,50$ & 6 & 17,65 \\
\hline & Toplam & 34 & 100 \\
\hline
\end{tabular}

\section{BULGULAR}

Yapılan çalışma kapsamında öğrenci kazanımları; Tablo 4'de verilen 3 başığa (motivasyon etkisi, eğitime katkı, mesleki deneyim) göre incelenmiş bulgular elde edilmiştir.

Bu doğrultuda; Tablo 4' de yapılan etkinliğin iç mimarlık eğitimine ve iç mimari mesleki donanıma olan katkısını ölçen 5 faktör ve her bir değişkenin faktörler altındaki ağırlıkları verilmiştir. Sonuçlara göre 5. Faktör toplam varyansın \%75,906'sını oluşturmaktadır. Sonuçlar bu faktör grubu (Mesleki Deneyim) altındaki ifadelerin diğer gruplar altındaki ifadelerden daha önemli olduğunu ortaya koymaktadır.

Bu grupta "Bir konuyu araştırarak başlayıp 3 boyutlu hale araştırmamı taşıdığım için kendimin öğrenme, araştırma ve uygulama konularında yeterli bir düzeyde yeteneklere sahip olduğumu gördüm (mesleki deneyim) (794)" ve "Mesleki donanımı kullanarak, çok farklı araştırmalar yapıp yürütebileceğimin farkındayım (mesleki deneyim) (849)" değişkenleri en büyük ağırlığı alan değişkenlerdir. Diğer yüksek değişkenler incelendiğinde 1 . faktör yükü altında "Anadolu dönem mimarisi hakkında daha net bir bilgi sahibi oldum (895)", "Anadolu hakkında daha net bir bilgi sahibi oldum (878) ve "Ihtiyaca yönelik mekânın şekillenmesi ne demek daha iyi anlayabiliyorum (860) (eğitime katkı) etkili olmuştur. Eğitime katkı grubu altındaki parametrelerden "Geçmişten Günümüze Anadolu'da Konut dersi sırasında yapılan çalışma incelediği konu hakkında kalıcı bilgi edinmemi sağladı (869)" parametresi 2.faktör yükü altında en yüksek sonucu almıştır. 3. Faktör yükü altında en yüksek sonuç ise "Konumu anlamak için gerekli araştırmayı yapmış olmam motivasyonumu sağladı (844)" parametresi olmuştur. Diğer bir yüksek faktör birimleri 4. Faktör altında "Araştırdığım dönemle ilgili teorik bilgiyi edinmiş oldum (857) ve "Tarihi dönemlerdeki mekân ihtiyacı ve mekân çözümü arasındaki bağlantıyı anladığımı düşünüyorum (811)" parametreleri olmuştur. 
Tablo 4. Çalışmanın iç mimarlık eğitimine olan katkısını ölçen faktör analizi sonuçları

\begin{tabular}{|c|c|c|c|c|c|c|}
\hline \multirow{2}{*}{\multicolumn{2}{|c|}{ Değişkenler }} & \multicolumn{5}{|c|}{ Faktör Yükleri } \\
\hline & & & & & & 5 \\
\hline \multirow{5}{*}{ 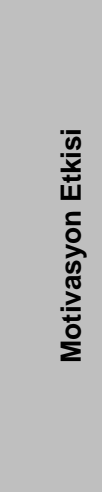 } & $\begin{array}{l}\text { Araştırma ve uygulamaya yönelik çalışmak motivasyonumu } \\
\text { sağladı }\end{array}$ & ,228 &, 509 & ,447 & ,481 &, 131 \\
\hline & $\begin{array}{l}\text { Konumu anlamak için gerekli araştırmayı yapmış olmam } \\
\text { motivasyonumu sağladı }\end{array}$ &, 113 & ,266 & ,844 & ,055 &,- 035 \\
\hline & $\begin{array}{l}\text { Araştırdığım konu içinde maketini yapacağım konutun pla- } \\
\text { nını seçmek motivasyonumu sağladı }\end{array}$ & ,407 & ,781 & ,271 &,- 147 & ,054 \\
\hline & $\begin{array}{l}\text { Araştırarak öğrendiğim tarihi mekânın planını çizmek moti- } \\
\text { vasyonumu sağladı }\end{array}$ &, 589 & ,233 & ,284 & ,337 &,- 172 \\
\hline & $\begin{array}{l}\text { Araştırarak öğrendiğim tarihi mekânın maketini yapmak } \\
\text { motivasyonumu sağladı }\end{array}$ & ,090 & ,055 & ,783 &, 055 & ,251 \\
\hline \multirow{9}{*}{ 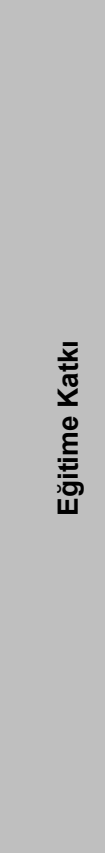 } & $\begin{array}{l}\text { Geçmişten Günümüze Anadolu'da Konut dersi sırasında } \\
\text { yapılan çalışma incelediği konu hakkında kalıcı bilgi edin- } \\
\text { memi sağladı }\end{array}$ &,- 008 & ,869 &,- 065 &, 163 &, 145 \\
\hline & Araştırdığım dönemle ilgili teorik bilgiyi edinmiş oldum &,- 024 & ,130 & 097 & ,857 &, 100 \\
\hline & Tarihi mekânları daha net öğrenmiş hissediyorum & ,780 & ,380 & ,026 & ,137 & $-0,13$ \\
\hline & $\begin{array}{l}\text { Geçmiş dönemlerde yapılan mekânların, yapım tekniklerini } \\
\text { daha iyi anlayabiliyorum }\end{array}$ & ,219 & ,716 & ,256 &, 118 &,- 172 \\
\hline & $\begin{array}{l}\text { Tarihi dönemlerdeki mekân ihtiyacı ve mekân çözümü ara- } \\
\text { sındaki bağlantıyı anladığımı düşünüyorum }\end{array}$ & ,115 &, 016 &, 117 &, 811 & ,312 \\
\hline & $\begin{array}{l}\text { İhtiyaca yönelik mekânın şekillenmesi ne demek daha iyi } \\
\text { anlayabiliyorum }\end{array}$ & ,860 & ,216 & 051 &, 027 &, 172 \\
\hline & Anadolu hakkında daha net bir bilgi sahibi oldum & ,878 &,- 061 &, 045 &,- 014 &,- 056 \\
\hline & $\begin{array}{l}\text { Anadolu dönem mimarisi hakkında daha net bir bilgi sahibi } \\
\text { oldum }\end{array}$ & ,895 &, 181 & 025 &,- 127 &, 115 \\
\hline & $\begin{array}{l}\text { Anadolu dönem mobilyası hakkında daha net bir bilgi sahibi } \\
\text { oldum }\end{array}$ & ,654 &,- 081 & ,470 & ,213 &, 037 \\
\hline \multirow{3}{*}{ 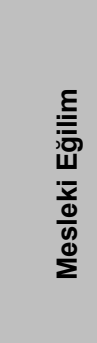 } & $\begin{array}{l}\text { Bir konuyu araştırarak başlayıp } 3 \text { boyutlu hale araştırmamı } \\
\text { taşıdığım için kendimin öğrenme, araştırma ve uygulama } \\
\text { konularında yeterli bir düzeyde yeteneklere sahip olduğumu } \\
\text { gördüm }\end{array}$ &,- 131 &,- 066 &, 142 & ,259 & ,794 \\
\hline & $\begin{array}{l}\text { Mesleki donanımı kullanarak, çok farklı araştırmalar yapıp } \\
\text { yürütebileceğimin farkındayım }\end{array}$ & ,247 &, 126 & ,179 & ,127 & ,849 \\
\hline & $\begin{array}{l}\text { Dersin bir zorunluluktan çok, kendimi ifade edebileceğim bir } \\
\text { paylaşım platformu olduğunu gördüm }\end{array}$ & ,020 & ,055 & ,586 & ,358 & ,363 \\
\hline
\end{tabular}

Bu doğrultuda: Geçmişten Günümüze Anadolu'da Konut dersi kapsamında yapılan çalışmada teorik bilginin maket etkinliği ile desteklenmesinin önemli olduğu görülmektedir. Yapılan bu uygulama çalışması "iç mimari eğitime katkı sağlanmasında" ve "iç mimari de mesleki bir donanım elde edilmesinde" yararlı bir uygulama olduğunu göstermiştir. Bu kazanımlar nitelikli bir iç mimarın gelişiminde ve mesleki yöneliminde önemli görülmektedir (Tablo 4). 
Deneyimsel Öğrenme Yöntemiyle Konut Tarihi Derslerinin Uygulanması: Geçmişten Günümüze Anadolu’da Konut Dersi Örneği

Tablo 5. Katıımcıların mesleki donanım farkındalığı ve farklı araştırmalar yapabilme konusunda eğilimleri

Katılımcılar

Sayı (N) Yüzde(\%)

\begin{tabular}{lcc}
\hline Kesinlikle Katılıyorum & 14 & 41,2 \\
\hline Katılıyorum & 11 & 32,4 \\
\hline Fikrim yok & 9 & 26,5 \\
\hline Katılmıyorum & - & - \\
\hline Kesinlikle Katılmıyorum & - & - \\
\hline Toplam & 34 & 100 \\
\hline
\end{tabular}

En yüksek faktör birimlerinden ve aktif değişkenlerden biri olan "katıımcıların mesleki donanım farkındalığı ve farklı araştırmalar yapabilme konusunda eğilimleri” sorusu incelendiğinde \%41,2 "kesinlikle katılıyorum", $\% 32,4$ "katılıyorum" ve \%9 "undan "fikrim yok" cevabı alınmıştır (Tablo 5).

Elde edilen bu verilere göre ders kapsamında yapılan maket çalışmasının, öğrencilerin mesleki bilgiyi edinme, bu tarz başka çalışmalar yapma isteğini ve ilgisini artırdığı görülmektedir. Mesleki yönelim ve bilgi açısından bu değişken oldukça önemlidir. Bu sonuç \% 41,2 ve 32,4 oranlarıyla "Katılımcıların mesleki donanım farkındalığı ve farklı araştırmalar yapabilmeleri konusunda eğilimlerinin olduğuna yönelik kesinlikle katılıyorum ve katılıyorum" cevabı ile desteklenmektedir (Tablo 5).
Ders kapsamında öğrencilerin iç mimari eğitim kazanımları incelendiğinde "Geçmişten Günümüze Anadolu'da Konut dersi sırasında yapılan çalışma incelediği konu hakkında kalıcı bilgi edinmemi sağladı" parametresi $\% 55,9$ oranla katılıyorum cevabı alınmıştır. Diğer sonuçlarda ise "Anadolu dönem mimarisi hakkında daha net bilgi sahibi oldum" \%50 (kesinlikle katılıyorum), "ihtiyaca yönelik mekânın şekillenmesi ne demek daha iyi anlayabiliyorum" \% 47,1 (kesinlikle katılıyorum) ve "tarihi mekânları daha net öğrenmiş hissediyorum" \% 44,1 (kesinlikle katılıyorum) sonuçları elde edilmiştir (Tablo 6). 
Tablo 6. Katıımcıların ders kapsamında mesleki eğilim yüzdeleri

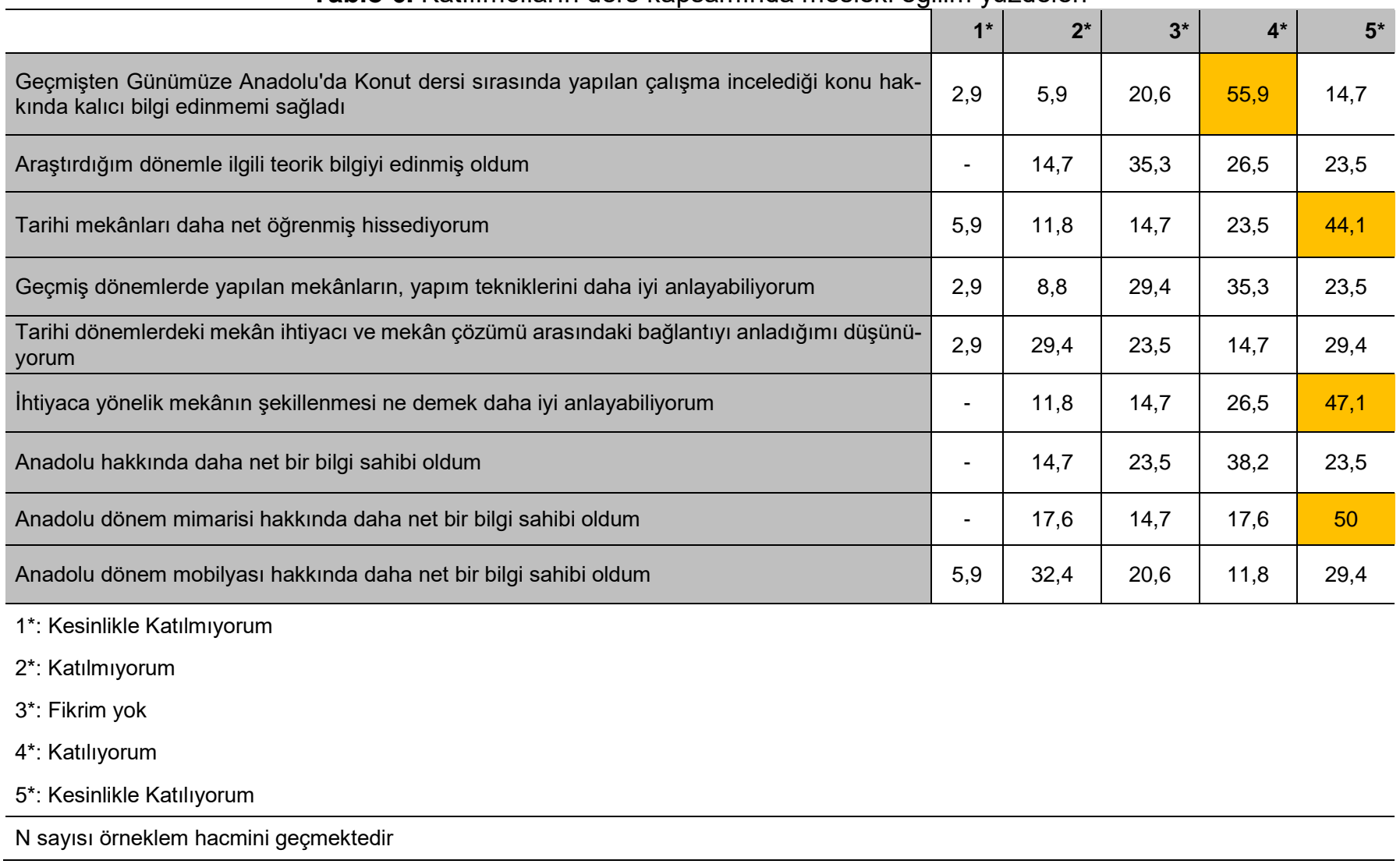

Bu doğrultuda; Geçmişten Günümüze Anadolu'da Konut dersi kapsamında yapılan etkinlik ve teorik bilgiye ulaşma konusunda olumlu bir ilişki olduğu görülmektedir. Bu nedenle öğrenci kazanımlarında tarihi dönemlerde mekânı ve Anadolu dönem mimarisinin öğrenildiği görülmektedir.

Öğrencilerin iç mimari mesleki eğilimleri ve bu çalışmanın eğitime olan katkısı arasındaki ilişkiyi belirlemek için korelasyon analizi yapılmıştır. Sonucunda parametreler arasındaki korelasyon analizi ile ilişki durumları belirlenmiştir. Pearson korelasyon katsayıları \%99 önem düzeyinde hesaplanmıştır (Tablo 7).

Analiz sonucunda mesleki eğilim parametreleri arasında yer alan "Bir konuyu araştırarak başlayıp 3 boyutlu hale araştırmamı taşıdığım için kendimin öğrenme, araştırma ve uygulama konularında yeterli bir düzeyde yeteneklere sahip olduğumu gördüm" ile eğitime katkı parametrelerinden olan "Tarihi dönemlerdeki mekân ihtiyacı ve mekân çözümü arasındaki bağlantıyı anladığımı düşünüyorum" parametresi arasında bir korelasyon olduğu görülmüştür ( $r=458)$. Mesleki eğilim parametreleri arasında yer alan "Bir konuyu araştırarak başlayıp 3 boyutlu hale araştırmamı taşıdığım için kendimin öğrenme, araştırma ve uygulama konularında yeterli bir düzeyde yeteneklere sahip olduğumu gördüm" ile "Mesleki donanımı kullanarak, çok farklı araştırmalar yapıp yürütebileceğimin farkındayım" parametresi arasında korelasyon tespit edilmiştir $(r=566)$. En yüksek korelasyon ise "Anadolu hakkında daha net bir bilgi sahibi oldum" ve "Anadolu dönem mimarisi hakkında daha net bir bilgi sahibi oldum" parametreleri arasında olduğu tespit edilmiştir $(r=769)$. Bir diğer yüksek korelasyon sonucu "Tarihi mekânları daha net öğrenmiş hissediyorum" ve "Ihtiyaca yönelik mekânın şekillenmesi ne demek daha iyi anlayabiliyorum" parametreleri arasında görülmektedir ( $r=752)$. Eğitime katkı parametreleri arasında olan "Ihtiyaca yönelik mekânın şekillenmesi ne demek daha iyi anlayabiliyorum" ve "Anadolu dönem mimarisi hakkında daha net bir bilgi sahibi oldum" parametreleri arasında da bir korelasyon olduğu görülmüştür ( $r=730)$.

Yapılan bu çalışmanın sonucu mesleki eğilim, eğitime katkı ve her iki kategori arasında ilişki olduğunu göstermektedir. Sonuçlara göre özellikle Anadolu tarihi, dönem mimarisi ve tarihi mekânın şekillenmesinin yapılan etkinlikle öğrenme sürecine olan katkısının önemini ortaya koymuştur. Öğrencilerin iç mimari mesleki deneyim edinmeleri ve bu eğitimin öğrencilere katkısı arasında olumlu bir ilişkinin olduğu çalışma kapsamında elde edilen sonuçlar arasındadır. Tüm verilere ait korelasyon bilgileri Tablo 7'de verilmiştir. 
Tablo 7. Ders kapsamında mesleki eğilim ve eğitime katkı arasındaki ilişki olduğu parametrelerin korelasyon tab-

\begin{tabular}{|c|c|c|c|c|c|c|c|c|c|c|c|c|}
\hline & & & & & & losu & & & & & & \\
\hline & A & B & C & D & E & $\mathbf{F}$ & G & $\mathbf{H}$ & I & $\mathbf{J}$ & $\mathrm{K}$ & $\mathbf{L}$ \\
\hline A & 1 & & & & & & & & & & & \\
\hline B &, $566^{\star *}$ & 1 & & & & & & & & & & \\
\hline C &, $396^{*}$ &, $420^{*}$ & 1 & & & & & & & & & \\
\hline D & ,014 & 0,219 & ,199 & 1 & & & & & & & & \\
\hline E & ,295 & ,256 &, $367^{*}$ & ,209 & 1 & & & & & & & \\
\hline $\mathbf{F}$ &,- 068 & ,191 & ,123 & ,316 & ,148 & 1 & & & & & & \\
\hline G &,- 043 & ,058 & ,153 &, $491^{* *}$ & ,157 &, $384^{*}$ & 1 & & & & & \\
\hline H &, $458^{\star *}$ &, $377^{*}$ &, $391^{*}$ & ,223 &, $589^{* *}$ & , 196 & , 165 & 1 & & & & \\
\hline$I$ & ,004 &, $404^{*}$ & ,099 & ,217 & ,035 &, $752^{* *}$ & ,249 & ,176 & 1 & & & \\
\hline $\mathbf{J}$ &,- 096 & , 165 &, 046 &,- 056 & , 026 &, $543^{\star *}$ & ,227 & ,043 &, $685^{* *}$ & 1 & & \\
\hline K &,- 091 & ,312 &, 104 & ,143 &,- 076 &, $725^{\star *}$ &, $347^{*}$ & ,040 &, $730^{* *}$ &, $769^{* *}$ & 1 & \\
\hline$L$ & ,030 & ,291 &, $357^{*}$ &,- 015 & ,213 &, $510^{* *}$ & ,300 & ,324 &, $513^{* *}$ &, $506^{* *}$ &, $625^{\star *}$ & 1 \\
\hline & & $\begin{array}{l}\text { A- Bir kon } \\
\text { konularınd }\end{array}$ & $\begin{array}{l}\text { araştıra } \\
\text { eterli bir }\end{array}$ & $\begin{array}{l}\text { başlayıp } \\
\text { zeyde ye }\end{array}$ & $\begin{array}{l}\text { boyutlu } \mathrm{r} \\
\text { neklere s }\end{array}$ & $\begin{array}{l}\text { le araştır } \\
\text { hip olduğ }\end{array}$ & $\begin{array}{l}\text { mı taşıc } \\
\text { I gördüı }\end{array}$ & için ke & $\min$ öğ & ne, araş & la ve uy & \\
\hline & tleri & B- Mesleki & nanımı k & anarak, ç & farklı ar & tırmalar $\mathrm{y}$ & ıp yürüt & ceğimi & arkındayı & & & \\
\hline & & C- Dersin & zorunlulu & an çok, k€ & dimi ifade & edebilece & bir pay & n platfc & u olduğu & gördüm & & \\
\hline & & $\begin{array}{l}\text { D- Geçmiş } \\
\text { memi sağl }\end{array}$ & Günüm & Anadolu & la Konut & rsi sırası & yapılar & şma in & ediği kc & hakkınd & Alıcı bilg & \\
\hline & & E- Araştıro & $n$ dönem & ilgili teori & bilgiyi edi & miş oldum & & & & & & \\
\hline & & F- Tarihi $\mathrm{m}$ & ânları da & net öğrer & niş hisseo & jorum & & & & & & \\
\hline & & G- Geçmiş & nemlerd & apılan m & kânların, \ & pım tekni & rini dah & anlaya & jorum & & & \\
\hline & tleri & $\mathrm{H}$ - Tarihi $\mathrm{d}$ & emlerdek & eekân ihti & $\mathrm{cl}$ ve me & àn çözüm & rasında & ğlantıy & רladığım & üşünüyo & & \\
\hline & & I- İhtiyaca & elik mek & In şekille & nesi ne $d$ & nek daha & anlayal & rum & & & & \\
\hline & & J-Anadolu & kkında c & la net bir & Igi sahibi & dum & & & & & & \\
\hline & & K- Anadolı & jnem mir & risi hakkı & da daha $n$ & bir bilgi & ibi oldu & & & & & \\
\hline & & L- Anadolu & nem mo & yası hakk & da daha & t bir bilgi & hibi oldu & & & & & \\
\hline
\end{tabular}

\section{SONUÇLAR}

Konut tarihi, mimarlık tarihi bütününde 20. Yüzyılın ortalarına doğru tartışılmaya başlamış ve günümüzde ne kadar önemli olduğu bilim dünyasınca kabul görmüştür. Bu bağlamda çalışmanın konusu olan Akdeniz Üniversitesi Mimarlık Fakültesi İç Mimarlık Bölümü öğrencilerine 2019-2020 Eğitim-Öğretim Güz yarıyılında ilk defa açılan Geçmişten Günümüze Anadolu'da Konut dersi de konut tarihini öğrenciye daha iyi aktarabilmek amacıyla açılmış 3. Sınıf seçmeli dersidir. Dersin işleyiş sürecinde anlatım, sunum, tartışma ve maket yapımı döngüsü kullanılarak öğrencilerinin maket yapım metodu ile eğitim süreçlerine katkıda bulunması hedeflenmiştir. Çalışma sonucunda elde edilen veriler ışığında Geçmişten Günü- müze Anadolu'da Konut dersi kapsamında, teorik bilginin maket etkinliği ile desteklenmesinin önemli olduğu yapılan analizler sonucunda tespit edilmiştir.

Bu ders kapsamında yapılan maket çalışmasının "iç mimari eğitime katkı sağlanmasında" ve "iç mimari de mesleki bir donanım elde edilmesinde" yararlı bir uygulama olduğunu göstermiştir. Yapılan analizlerden ortaya çıkan diğer bir bulgu, Anadolu tarihi, dönem mimarisi ve tarihi mekânın şekillenmesinin yapılan etkinlikle öğrenme sürecine önemli katkı sağlamasıdır. Teorik bir dersin uygulamalı olarak işlenmesi dersin ilk haftalarında öğrencilerin çok hoşuna giden bir durum olmasa da 6 . haftadan sonra tüm öğrenciler derse adapte olarak dersi başarılı bir şekilde tamamlamışlardır. Ayrıca dersin sonucunda ortaya çıkan maketlerin fakültenin iç avlusunda kalıcı 
olarak sergilenmeye başlamıştır. Bu kalıcı sergi, dersi alanı tüm öğrencileri memnun etmiştir. Ayrıca sergi fakültede bulunan diğer öğrencilerinin de ilgisini çekmiş onların da konut hakkında bilgi sahibi olmasına dolaylı yoldan fayda sağlamıştır.

Sonuç olarak İç Mimarlık Bölümlerinde Proje derslerinin yanında hep ikinci planda kalan tarih derslerinin, öğrencinin aşina olduğu maket yapma yöntemi ile işlenmesi öğrenci açısından son derece verimli olmuştur.

\section{TEŞEKKÜR}

$\mathrm{Bu}$ çalışma boyunca desteklerini bizden esirgemeyen Sayın Akdeniz Üniversitesi Mimarlık Fakültesi Dekanı ve Dekan yardımcısına, Akdeniz Üniversitesi Mimarlık Fakültesi İç Mimarlık Bölüm Başkanlığına, tüm teknik bilgilerini bize aktaran Sayın Mimar Zeki Bellikli'ye, Fotoğraf çekimleri sırasında büyük destek veren Usta Öğretici Burak Eldek'e ve Geçmişten günümüze Anadolu'da Konut dersini alan ve büyük bir özveri ile çalışan Akdeniz Üniversitesi Mimarlık Fakültesi İç Mimarlık Bölümü'nün 34 öğrencisine teşekkür ederiz.

\section{KAYNAKLAR}

Akok, M. (1951). Ankara'nın Eski Evleri, Ankara Türk Tarih Kurumu Basın Evi.

Durukan, A. (2020). Ayşegül Durukan E-Arşivi.

Düring, B. S. (2010). The prehistory of Asia Minor: from complex hunter-gatherers to early Urban societies. Cambridge University Press.

Ertaş Beşir, Ş., Odacı, G.S., Bekar, M., Açıkel, M., Sümerka, M.R. (2020). Tarihi ve Kültürel Özellikleri İçeren Bir Çevrede Gerçekleşen Teknik Gezilerin İç Mimarlık Öğrencilerinin Kazanımlarına Etkisi: Trabzon Çaykara Bölgesi Örneği. Mehmet Akif Ersoy Üniversitesi Fen Bilimleri Enstitüsü Dergisi 11(1): 95-107.

Güler, K. (2012). Doğu Karadeniz Kırsal Mimarisi Örneklerinden Rize-Fındıklı Aydınoğlu Evi Restorasyon Projesi İstanbul Teknik Üniversitesi, Fen Bilimleri Enstitüsü, Mimarlık Ana Bilim Dalı, Restorasyon Programı, Yüksek Lisans Tezi, İstanbul.
Harris, K., Marcus, R., Mclaren, K. ve Fey, J. (2001). Curriculum Materials Supporting Problem-Based Teaching, School Science \& Mathematics, 101(6): 310-318.

Izadpanah, S., Kaynakcı Elinç, Z., Söyek Abay, B., Küçükköseler, T. (2020). Türkiye'deki İçmimarlık Eğitiminde Staj Uygulamalarının Değerlendirilmesi. Uluslararası Mühendislik, Tasarım ve Teknoloji Dergisi 2(1): 1-9.

Karahan, S. (2016) Türkiye'de Çağdaş Mimarlık Eğitiminde Mimarlık Tarihi Disiplininin Yeri. Erciyes Üniversitesi, Fen Bilimleri Enstitüsü, Mimarlık Anabilim Dalı, Yüksek Lisans Tezi, Kayseri.

Kavas K.R. (2009) Sanat Tarihi - Mimarlık Tarihi Arasındaki Değişen İlişkilerin Sivil Konut Mimarisi Araştırmaları Bağlamında Değerlendirilmesi, Akdeniz Sanat, 4: 37-46.

Kuban, D. (2018). Türk Ahşap Konut Mimarisi. Türkiye İş Bankası Kültür Yayınları, İstanbul.

Memiş, B. (1997). Urartu Konut Mimarlığı. İstanbul Üniversitesi, Sosyal Bilimler Enstitüsü Eskiçağ Tarihi Anabilim Dalı, Yüksek Lisans Tezi, İstanbul.

Oral, E. Ö. (1996). Antalya Kaleiçi'nde Hakkı Misistreli Evi ve Tekeli Evi Restorasyon Projeleri. İstanbul Teknik Üniversitesi, Fen Bilimleri Enstitüsü, Yüksek Lisans Tezi, İstanbul.

Özdeniz, M.B., Bekleyen, A., Gönül, I. A., Gönül, H., Sarıgül, H., Ilter, T., Dalkılıç, N., \& Yıldırım, M. (1998). Vernacular domed houses of Harran, Turkey. Habitat International, 22 (4): 477-485

Özlük, S. (2019). Türkiye'de Konut Sorunu. İkinci Adam Yayınları, İstanbul.

Rumscheid, F. (2000). Küçük Asya'nın Pompeisi Priene Rehberi. Ege Yayınları, İstanbul.

Sey, Y. (1999). Tarihten Günümüze Anadolu'da Konut ve Yerleşme, Türkiye Ekonomik ve Toplumsal Tarih Vakfı, İstanbul.

Strabon. (2000). Antik Anadolu Coğrafyası (Geographika XIIXIII-XIV) Çev. Adnan Pekman, Arkeoloji ve Sanat Yayınları, (4. Baskı), Kanaat Basımevi, İstanbul.

Tosun, M.N. (1998). Zeyrek İbadethane Sokak 33 No'lu Evin Restorasyon Projesi, İstanbul Teknik Üniversitesi, Fen Bilimleri Enstitüsü, Yüksek Lisans Tezi, İstanbul.

Uğur, O. L., Balcı, B. (2014). 2002-2012 Yılları Arasında T.C. Hükümetlerinin Konut Edindirme Politikalarının İrdelenmesi. Düzce Üniversitesi Bilim ve Teknoloji Dergisi, 2: 333351.

URL-1 (2019). https://sanalmuze.gov.tr/TR-259961/anadolumedeniyetleri-muzesi---ankara. html (Erişim Tarihi: 15.11.2019).

URL-2 (2019). http://www.matu.com.tr/mimarlik/projeler.asp?pid=174 (Erişim Tarihi: 13.11.2019). 